\title{
Mixed Plantations of Eucalyptus and Leguminous Trees: Soil, Microbiology, and Ecosystem Services
}

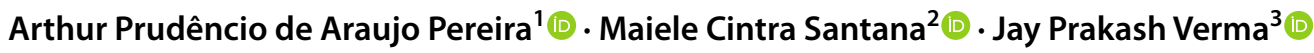

Received: 26 July 2021 / Revised: 11 August 2021 / Accepted: 12 August 2021 / Published online: 26 August 2021

(c) The Author(s), under exclusive license to Springer Nature Singapore Pte Ltd. 2021

Mixed forest plantation represents a key strategy for sustainable silviculture in the Anthropocene (Popkin 2019). The introduction of leguminous trees in a mixed system can reduce the utilization of synthetic inputs such as mineral fertilizers and pesticides (Laclau et al. 2018). Thus, in addition to reducing the production costs, mixed forest systems can also eliminate the risks of environmental contamination (Pereira et al. 2020). Several field experiments showed positive results using acacia trees intercropped with Eucalyptus. Acacia is a leguminous tree highly efficient in promoting biological nitrogen fixation through the root-associated diazotrophic bacteria, besides making associations with different types of endo/ectomycorrhizal fungi (Paula et al. 2018; Pereira et al. 2019). Also, the microbiome related to acacia can provide innumerable benefits to the surrounding soil and plants. The intercropped system between Acacia mangium and Eucalyptus grandis has been the most recently studied mixed plantation approach. The vast majority of the experiments conducted across the globe show that mixed systems are more productive than monocultures (pure plantations). However, all the changes in soil properties and ecosystem services promoted by these tree's association have been never compiled in detail. In this way, the main aim of the book "Mixed Plantations of Eucalyptus and Leguminous Trees: Soil, Microbiology and Ecosystem Services" edited by Elke Jurandy Bran Nogueira Cardoso, José Leonardo de Moraes Gonçalves, Fabiano de Carvalho Balieiro and Avílio Antônio Franco, Springer Nature (Price eBook: 11,769 $€$ and Hardcover: 14,559 €; eISBN: 978-3-030-32365-3, ISBN:

Arthur Prudêncio de Araujo Pereira

arthur.prudencio@ufc.br

1 Soil Science Department, Federal University of Ceará, Fortaleza, Ceará, Brazil

2 Luiz de Queiroz College of Agriculture, University of São Paulo, Piracicaba, São Paulo, Brazil

3 Institute of Environment and Sustainable Development, Banaras Hindu University, Varanasi, Uttar Pradesh, India
978-3-030-32364-6; https://doi.org/10.1007/978-3-03032365-3), was to show a holistic view regarding the economic and ecological perspectives of the mixed plantations systems, mainly focusing on the ecosystem services (Fig. 1).

To better introduce the rationale of the book, it is necessary to think about the following question: why mixed forest plantations? The primordial answer can be based on the statement of the editors "because, when comparing all forests management systems implanted in poor soils, the mixed plantation is socially more advantageous and benefitting the rural entrepreneur economically, besides its high sustainability". Most of the Eucalyptus plantations in Brazil are concentrated in the Cerrado biome (Brazilian savanna), where there is a predominance of highly weathered and, consequently, low fertility soils, especially the Oxisols (Gonçalves et al. 2013). In addition, the eucalyptus distributes a large amount of nutrients, sometimes more than those applied in the soil through mineral fertilization (Pulito et al. 2015). However, this discrepancy (negative balance) is less pronounced in the mixed system with acacia (Bouillet et al. 2008; Pereira et al. 2018). In this way, the replacement of mineral fertilizer for a mixed system with leguminous trees is an interesting solution for a more sustainable, economically suitable, and cleaner forest system (Pereira et al. 2017, 2019).

This book is unique in terms of providing insight into mixed forests plantation using leguminous trees and its application to improve Eucalyptus production. This thematic represents an especially important topic for Brazil and worldwide. For example, in Brazil alone, it is possible to find around 7.8 million hectares of planted forests with eucalyptus. This amount is important in various aspects because it can act in the ecological, social, and economic factors in the country, as well as reduce the pressure in the native forests (e.g., Amazon) and generating direct and indirect jobs (Ibá 2015). However, the sustainability of these forests remains uncertain, mainly when are evaluated the factors related to the biogeochemical cycle of nutrient and, more importantly, 


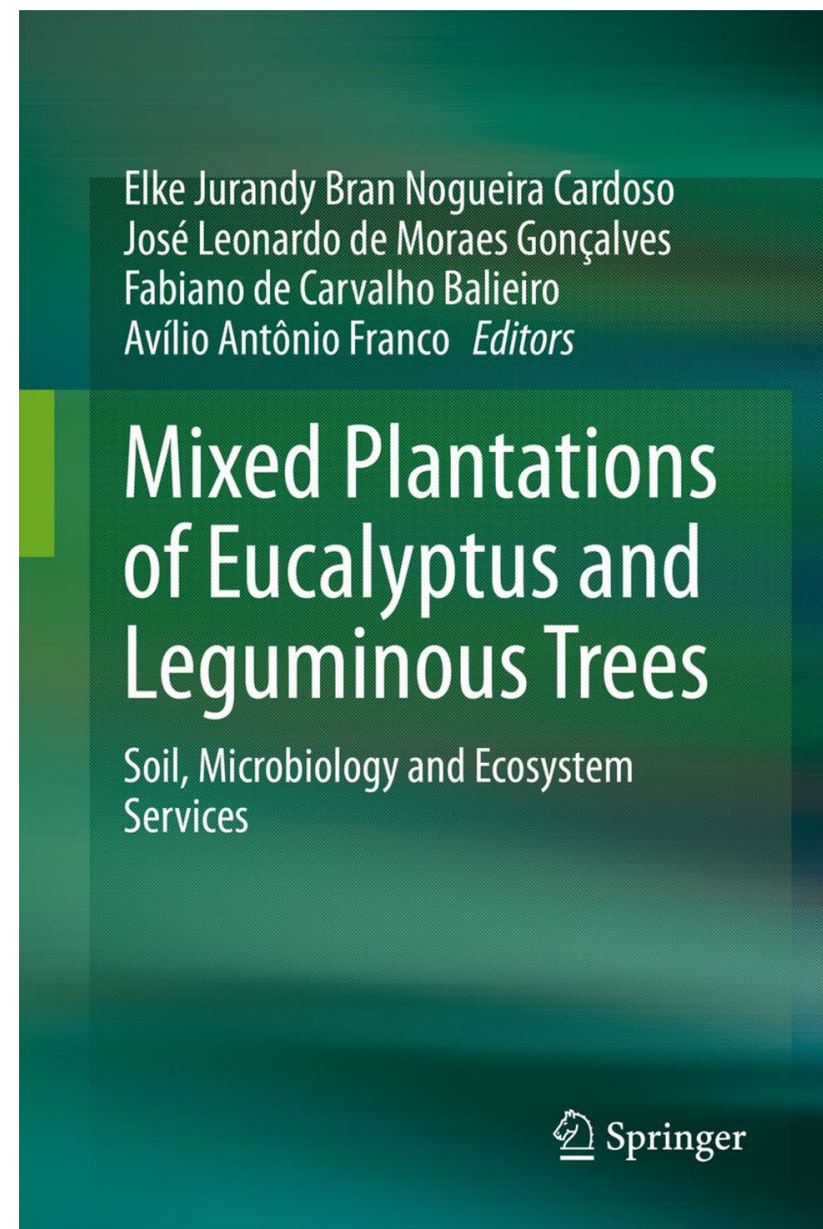

Fig. 1 Cover page of the book

the ecosystem services (Laclau et al. 2008; Rocha et al. 2016). These factors hold crucial relevance in the priority list of the Food and Agriculture Organization (FAO) and UN-Sustainable Development Goals (UN-SDGs).

The book comprises 13 chapters, framed by 37 experts of their fields, which covers Eucalyptus and acacia association (above and belowground) as key subject areas. As evident from the title of the book, the editors categorize the book into sections that cover the core themes: mixed Eucalyptus plantation with leguminous trees, whereas soil microbiome and ecosystem services was a related perspective throughout the book extension. Moreover, nutrient cycling, carbon, and nitrogen stocks are considered as the key attributes to improve eucalyptus nutrition and productivity.

The first chapter introduces the history and the major issues and challenges to adopt mixed forest plantations. Chapter 1 briefly shows several benefits and potentials related to productivity and ecosystem services obtained when Eucalyptus and $\mathrm{N}_{2}$-fixing species are involved in the same area. The second chapter focuses on the above- and -belowground growth patterns of mixed Eucalyptus and Acacia. The third chapter discusses the different aspects associated with nutrient cycling in the soil and litter layers. The fourth chapter highlights the recent information about the effect of Acacia association with Eucalyptus on the litter decomposition and its result on the soil $\mathrm{C}$ accumulation/stabilization. The fifth chapter describes the bacterial community, focusing on the major drivers that module their dynamics in pure and mixed eucalyptus and Acacia plantations. The sixth chapter is particularly important because it demonstrates the aspects of biological nitrogen fixation (BNF) promoted by Acacia when in a mixed system with Eucalyptus. The BNF represents the key ecological strategy to reduce the use of $\mathrm{N}$ fertilizers, improving eucalyptus productivity with reasonable cost (Laclau et al. 2008; Vicente and Dean 2017; Paula et al. 2018). The seventh chapter highlights the current finds related to mycorrhizal associations in mixed plantations, on the surface to the deep soil layers. Together, both BNF and the mycorrhizal process can increase Eucalyptus nutrition in $\mathrm{N}$ and $\mathrm{P}$ improved by the acacia root system (Tedersoo et al. 2020; Emmett et al. 2021). The eighth chapter attempts to show how the pure and mixed Eucalyptus plantations provide niches and nutrient sources to the survival of meso and macrofauna. Besides these important chapters, the ninth chapter demonstrates the principal bioindicators of soil quality in mixed plantations and their associated benefits. The tenth chapter discusses ecosystem services provided by acacia trees associated with eucalyptus in a multifunctional view of these plantations in Brazil. Because it is an exotic plant, the 11th chapter shows the risks of acacia invasions in Brazilian forests. On the other hand, the 12 th chapter details the high potential of mixed forest plantations using Brazilian native leguminous trees for timber and non-timber products, recuperation of degraded soils, and environmental services. The last chapter is dedicated to showing the Brazilian legal framework of the multifunctional mixed planted forests.

This book is good for all scientific communities related to forest sciences, from academies to industries. Also, this book is recommended for agricultural students, biologists, environmental engineers, and undergraduate and graduate students in these areas for a better understanding of Eucalyptus soil and its importance for environmental and ecological sustainability. This book is not only specific for Brazilian readers, but also these studies are presented and can be extremely useful for global readers.

As per our perception, the editors could have included some chapters regarding the impact of mixed plantations on reducing greenhouse gas emissions as well as the detailed impacts of such plantations on socio-ecological resilience. It 
may be another key factor that emphasizes the importance of mixed plantations for ecosystem stability and sustainability (Luyssaert et al. 2018; Popkin 2019; Cavicchioli et al. 2019; Hermans et al. 2020).

Acknowledgements The author is grateful to FAPESP for providing the fellowship (Proc. no. 13/12279-0 and 16/01636-4).

\section{Declarations}

Conflict of interest On behalf of all authors, the corresponding author states that there is no conflict of interest.

\section{References}

Bouillet JP, Laclau JP, Gonçalves JLM, Moreira MZ, Trivelin PCO, Jourdan C, Silva EV, Piccolo MC, Tsai SM, Galiana A (2008) Mixed-species plantations of Acacia mangium and Eucalyptus grandis in Brazil. For Ecol Manage 255:3918-3930. https://doi. org/10.1016/j.foreco.2007.10.050

Cavicchioli R, Ripple WJ, Timmis KN et al (2019) Scientists' warning to humanity: microorganisms and climate change. Nat Rev Microbiol 17:569-586. https://doi.org/10.1038/s41579-019-0222-5

Emmett BD, Lévesque-Tremblay V, Harrison MJ (2021) Conserved and reproducible bacterial communities associate with extraradical hyphae of arbuscular mycorrhizal fungi. ISME J 15:2276-2288. https://doi.org/10.1038/s41396-021-00920-2

Gonçalves JLM, Alvares CA, Higa AR, Silva LD, Alfenas AC, Stahl J, Ferraz SFB, Lima WP, Brancalion PHS, Hubner A, Bouillet JPD, Laclau JP, Nouvellon Y, Epron D (2013) Integrating genetic and silvicultural strategies to minimize abiotic and biotic constraints in Brazilian eucalypt plantations. For Ecol Manage 301:6-27. https://doi.org/10.1016/j.foreco.2012.12.030

Hermans SM, Buckley HL, Case BS et al (2020) Using soil bacterial communities to predict physico-chemical variables and soil quality. Microbiome 8:79. https://doi.org/10.1186/ s40168-020-00858-1

Ibá A (2015) Indústria brasileira de Árvores. Anu Estatístico Da IBA 100:74. https://doi.org/10.1007/s13398-014-0173-7.2

Laclau JP, Bouillet JP, Gonçalves JLM, Silva EV, Jourdan C, Cunha MCS, Moreira MR, Saint-André L, Maquère V, Nouvellon Y, Ranger J (2008) Mixed-species plantations of Acacia mangium and Eucalyptus grandis in Brazil. For Ecol Manage 255:39053917. https://doi.org/10.1016/j.foreco.2007.10.049

Luyssaert S, Marie G, Valade A, Chen YY, Njako DS, Ryder J, Otto J, Naudts K, Sofie Lansø A, Ghattas J, McGrath MJ (2018)
Trade-offs in using European forests to meet climate objectives. Nature 12:74. https://doi.org/10.1038/s41586-018-0577-1

Paula RR, Bouillet JPM, Gonçalves JL, Trivelin PCO, Balieiro FC, Nouvellon Y, Bordron B, Laclau JP (2018) Nitrogen fixation rate of Acacia mangium Wild at mid rotation in Brazil is higher in mixed plantations with Eucalyptus grandis Hill ex Maiden than in monocultures. Ann for Sci 75:14. https://doi.org/10.1007/ s13595-018-0695-9

Pereira APA, Andrade PAM, Bini D, Robin A, Bouillet JP, Andreote FD, Cardoso EJBN (2017) Shifts in the bacterial community composition along deep soil profiles in monospecific and mixed stands of Eucalyptus grandis and Acacia mangium. PLoS ONE 12:e0180371. https://doi.org/10.1371/journal.pone.0180371

Pereira APA, Zagatto MRG, Brandani CB (2018) Acacia changes microbial indicators and increases $\mathrm{C}$ and $\mathrm{N}$ in soil organic fractions in intercropped Eucalyptus plantations. Front Microbiol 9:1-13. https://doi.org/10.3389/fmicb.2018.00655

Pereira APA, Durrer A, Gumiere T, Gonçalves JLM, Robin A, Bouillet JP, Wang J, Verma JP, Singh BK, Cardoso EJBN (2019) Mixed Eucalyptus plantations induce changes in microbial communities and increase biological functions in the soil and litter layers. For Ecol Manage 433:332-342. https://doi.org/10.1016/j.foreco. 2018.11.018

Pereira APA, Bini D, Rodrigues EG, Santana MC, Cardoso EJBN (2020) Bioindicators of soil quality in mixed plantations of eucalyptus and leguminous trees. In: Bran Nogueira Cardoso E, Gonçalves J, Balieiro F, Franco A (eds) Mixed plantations of eucalyptus and leguminous trees. Springer, Cham. https://doi.org/10. 1007/978-3-030-32365-3_9

Popkin G (2019) How much can forests fight climate change? Nature 565:280-282. https://doi.org/10.1038/d41586-019-00122-z

Pulito AP, Gonçalves JLM, Smethurst PJ, Junior JCA, Alvares CA, Rocha JHT, Hübner AMLF, Miranda AC, Kamogawa MY, Gava JL, Chaves R, Silva CR (2015) Available nitrogen and responses to nitrogen fertilizer in brazilian eucalypt plantations on soils of contrasting texture. Forests 6:973-991. https://doi.org/10.3390/ f6040973

Rocha JHT, Gonçalves JLM, Gava JL, Godinho TO, Melo EASC, Bazani JH, Hubner A, Arthur Junior JC, Wichert MP (2016) Forest residue maintenance increased the wood productivity of a Eucalyptus plantation over two short rotations. For Ecol Manage 379:1-10. https://doi.org/10.1016/j.foreco.2016.07.042

Tedersoo L, Bahram M, Zobel M (2020) How mycorrhizal associations drive plant population and community biology. Science 367:6480eaba1223. https://doi.org/10.1126/science.aba1223

Vicente EJ, Dean DR (2017) Keeping the nitrogen-fixation dream alive. Proc Nat Acad Sci 114:3009-3011. https://doi.org/10.1073/pnas. 1701560114 